\title{
Conventional and Molecular Detection of Listeria monocytogenes and its Antibiotic Sensitivity Profile from Cattle Sources of Aizawl, Mizoram (India)
}

\author{
Papia Biswas $^{1 *}$, Devajani Deka1 ${ }^{1}$ T.K. Dutta ${ }^{2}$, E. Motina ${ }^{1}$ and P. Roychoudhury ${ }^{2}$ \\ ${ }^{1}$ Department of Veterinary Public Health \& Epidemiology, ${ }^{2}$ Department of Veterinary \\ Microbiology, College of Veterinary Sciences \& AH, Central Agricultural University, Selesih, \\ Aizawl, Mizoram, 796014, India \\ *Corresponding author
}

\begin{tabular}{|l|}
\hline K e y w o r d s \\
$\begin{array}{l}\text { Listeria monocytogenes, } \\
\text { PCR, Antibiotic } \\
\text { sensitivity, Aizawl, } \\
\text { Mizoram }\end{array}$ \\
\hline Article Info \\
\hline $\begin{array}{l}\text { Accepted: } \\
22 \text { October } 2018 \\
\text { Available Online: } \\
10 \text { November } 2018\end{array}$ \\
\hline
\end{tabular}

\section{A B S T R A C T}

The present study was conducted to study the prevalence of the food borne zoonotic pathogen of animal origin, L. monocytogenes by isolation and identification, molecular detection and antibiotic sensitivity pattern from different samples of cattle sources in Aizawl district of Mizoram. A total 200 numbers of sample including cattle faeces (50), raw milk (50) and milk products (100) were collected randomly from different unorganized shop and farms. The seasonal variation in the occurrence of $L$. monocytogenes was also studied. The L. monocytogenes was isolated by using two step enrichment method of culturing and identified based on cultural characteristics, gram staining, biochemical properties, tumbling motility and in vitro pathogenicity tests. The molecular detection of $L$. monocytogenes strains were done by PCR using published primers. The antibiotic sensitivity was studied against 12 numbers of commonly used antibiotics in animals and human. The prevalence of $L$. monocytogenes was recorded as 6.50 percent including 8.00 percent from cattle faeces, 6.00 percent from raw milk, 8.00 percent from lassi, dahi and ice-cream samples, respectively. The L. monocytogenes strains showed 100 percent sensitivity towards Penicillin, Ampicillin, Oxacillin, Cephotaxime/Clavulanic acid, Ciprofloxacin, Tetracycline and Trimethoprim/Sulphamethoxazole followed by Streptomycin (84.61\%), Chloramphenicol (53.84\%), Gentamicin (53.84\%) and Ceftriaxone (46.15\%).

\section{Introduction}

Listeriosis has been among important food borne zoonotic diseases since long, mostly due to its high mortality rate despite of being uncommon in human beings (Atil et al., 2011). The severity of the disease has become significant as the causative organism Listeria monocytogenes is the most important species in the genus can be secreted through milk of both healthy and infected animals (Wagner $e t$ al., 2000). This is still called an emerging pathogen as its transmission through contaminated food is recently recognized. $L$. monocytogenes is a gram positive, ubiquitous, non-spore forming organism that can survive a 
wide range of $\mathrm{pH}$ from 4.0-9.6 and temperature from $-1.5^{\circ} \mathrm{C}$ to $45^{\circ} \mathrm{C}$ (Lado and Yousef, 2007). Listeriosis is commonly characterized by meningoencephalitis, generalised septicaemia and abortion (Late pregnancy) in both human and animals. Young individuals along with immunocompromised ones are more susceptible than others. Way back in 1985, Listeriosis was declared as serious public health hazards (Rocourt and Catimel, 1985).

Listeria spp. have been reported as susceptible to antibiotics active against gram positive bacteria but in recent years like many other bacterial pathogens Listeria are developing resistance to many currently used antibiotics. Current choice of antibiotics for all forms of listeriosis is combination of Ampicillin and Gentamicin (Schlech and Acheson, 2000). The studies on $L$. monocytogenes in the perspective of foodborne pathogen are scanty in North-East Region states of India including Mizoram. Therefore keeping the above points in view, the present study was undertaken to isolate, identify and to study the prevalence and antimicrobial sensitivity pattern of $L$. monocytogenes from different samples of cattle source $s$ in Aizawl district of Mizoram.

\section{Materials and Methods}

\section{Study area}

The present study on isolation and identification, molecular detection and antimicrobial sensitivity pattern of $L$. monocytogenes from different samples of cattle sources was carried out in Aizawl district of Mizoram. It is mainly a hilly state of North-eastern region. It extends from $21^{\circ} 56^{\prime} \mathrm{N}$ to $24^{\circ} 31^{\prime} \mathrm{N}$, and $92^{\circ} 16^{\prime} \mathrm{E}$ to $93^{\circ} 26^{\prime} \mathrm{E}$. It is the 2 nd least populous state in the country and it is covers an area of approximately 21,087 square kilometres. About 91percent of the area in the state is forested.

\section{Period of the study}

The study was conducted for a period of one year from July, 2017 to June, 2018 and the study period was divided into two halves; Summer (March to September) and Winter (October to February).

\section{Collection of Samples}

A total of 200 numbers of faecal samples of cattle, raw milk and milk products were collected randomly from different unorganized cattle farms/ milk vendors/ shops periodically during the study period by following aseptic measures for detection of L. monocytogenes during the study period. Distributions of different samples collected are given in the Table 1.

\section{Isolation and phenotypic characterization of L. monocytogenes}

\section{Enrichment of faecal sample}

The USDA (USDA FSIS, 2002) method was employed for isolation of Listeria spp. from faecal samples of cattle by two step enrichment method. Primary enrichment of five grams of faecal sample was done in $45 \mathrm{ml}$ $1 / 2$ strength UVM-I broth containing selective supplements (HiMedia Pvt. Ltd., Mumbai) ${ }^{\circledR}$ and incubated for 24 hours at $30^{\circ} \mathrm{C}$ followed by secondary enrichment of $0.1 \mathrm{ml}$ from the primary broth culture in $10 \mathrm{ml}$ UVM-II broth containing selective supplements and incubated for 48 hours at $37^{\circ} \mathrm{C}$.

\section{Enrichment of milk and milk products}

Food and Drug Administration (2015) testing methodology with slight modification was employed for isolation and identification of $L$. monocytogenes from cattle faeces, raw milk and milk products (lassi, dahi, ice-cream and rasmalai). Twenty five $\mathrm{ml}$ of sample was 
mixed with $225 \mathrm{ml}$ of UVM broth properly for 2 minutes and the mixture was incubated at 30 $\pm 2^{\circ} \mathrm{C}$ for 24 hours. For secondary enrichment, $0.1 \mathrm{ml}$ of the cultured UVM was transferred to $10 \mathrm{ml}$ of Fraser broth (FB) and incubated at $37^{\circ} \mathrm{C}$ for $24 \pm 2$ hours.

Selective plating of $L$. monocytogenes (UVM-Broth and FB culture) in PALCAM, McBride and TSYEA agar

A drop of approximately $0.1 \mathrm{ml}$ of FB broth culture turning to black colour was streaked aseptically upon PALCAM and McBride agar plates and the plates were incubated at $37^{\circ} \mathrm{C}$ for 24-48 hours. The suspected colonies on PALCAM/ McBride agar plates were streaked with the help of a sterile loop on TSYEA plate and incubated at $37^{\circ} \mathrm{C}$ for 24 hours and subsequently tested for further biochemical and in vitro pathogenicity characteristics.

\section{Morphological and biochemical characteristics of L. monocytogenes}

The L.monocytogenes strains were phenotypically characterized by morphological characteristics, Gram staining reaction and biochemical characteristics (Catalase, Oxidase, Motility, Indole, Methyl Red, Voges-Proskauer, Citrate utilization, fermentation patterns of sugars like LRhamnose, D-Xylose and Mannitol etc.) (Quinn et al., 1994).

\section{In vitro pathogenicity test}

\section{Beta haemolysis test on five percent sheep} blood agar

The suspected colonies on PALCAM/ McBride/ TSYEA agar plates were streaked on five percent Sheep Blood Agar (SBA) plates and the plates were incubated at $37^{\circ} \mathrm{C}$ for 24 hours. The L. monocytogenes positive SBA plate showed translucent colonies surrounded by a small zone of $\beta$-haemolysis after back light.

\section{Christie, Atkins, Munch- Petersen (CAMP) Test}

The presence of in-vitro pathogenicity of $L$. monocytogenes by CAMP test was as per the method of ISO (1996). The standard strains of Rhodococcus equi (MTCC 8144) and Staphylococcus aureus (MTCC 43300) were streaked on freshly prepared 5 percent SBA plates wide apart and parallel to each other. The test strains were streaked at $90^{\circ}$ angle to $R$. equi and $S$. aureus with a distance of three $\mathrm{mm}$ apart from these strains streaking line.

The streaked plates were incubated for 24 hours at $37^{\circ} \mathrm{C}$ and examined for haemolytic zone from partial haemolysis to a wider zone of complete haemolysis. The isolates with CAMP- positivity against $S$. aureus were characterized as L. monocytogenes giving a spade shaped haemolytic zone formation.

\section{Molecular detection of $L$. monocytogenes}

\section{Bacterial lysate preparation}

All the culturally, phenotypically and biochemically positive L. monocytogenes isolates were processed for bacterial lysate preparation using boiling and snap chill method. A single colony of phenotypically confirmed strain was inoculated into one $\mathrm{ml}$ of $\mathrm{LB}$ broth and incubated at $37^{\circ} \mathrm{C}$ for $16-18$ hours. After overnight incubation at $37^{\circ} \mathrm{C}$, cells were pelleted by centrifugation at 8000 rpm for 10 minutes at $4^{\circ} \mathrm{C}$. Then the pellet was washed three times with sterile normal saline solution $(0.85 \%)$ and finally re-suspended in $500 \mu 1$ of nuclease free sterile distilled water. The cell suspension was heated in a boiling water bath for five minutes followed by immediate chilling. The cellular debris was sediment by centrifugation at $5000 \mathrm{rpm}$ for 
five minutes. The supernatant was used as template DNA for PCR assay.

Detection of species specific gene (16SrRNA) of L. monocytogenes isolates by PCR

All the culturally, phenotypically and biochemically positive L. monocytogenes isolates were subjected for $16 S-r R N A$ species specific gene amplification by PCR using published primer and according to the methodology described by Jallewar et al., (2007). The details about the primer sequence are given at Table 2. The PCR assay was carried out in $0.2 \mathrm{ml}$ thin PCR tube. To detect species specific genes of L. monocytogenes, the PCR protocol was standardized by using standard L. monocytogenes (MTCC 1143) as positive control and sterile milli-Q water as negative control. The final composition for 25 $\mu l$ reaction mixture is given at Table 3 .

Amplification of DNA was performed in a Thermal cycler machine with a pre-heated lid. The detail of the cycling condition for the species specific gene was given in the Table 4. All the amplified PCR products were analyzed by agarose gel electrophoresis using one percent agarose gel in $1 \mathrm{X}$ TAE buffer $(\mathrm{pH}$ 8.0). About five $\mu 1$ of PCR product was mixed with $2 \mu$ of $6 \mathrm{X}$ gel loading dye and loaded into each well. DNA ladder (3000 bp) was used as reference to compare the size of amplified products. The gel was visualized under UV transilluminator (Alpha Imager) and documented by gel documentation system (Alpha Imager).

Detection of antibiotic sensitivity and resistance pattern of $L$. monocytogenes strains

All the L. monocytogenes isolates were subjected to in vitro antibiotic sensitivity test by disc diffusion method (Bauer et al., 1966) against a panel of 12 antibiotics namely
Penicillin G, Ampicillin, Oxacillin, Streptomycin, Erythromycin, Cephotaxime/ Clavulanic acid, Ceftriaxone, Chloramphenicol, Ciprofloxacin, Gentamicin, Tetracycline and Trimethoprim/ Sulphamethoxazole as per Clinical and Laboratory Standard Institute (CLSI) guidelines (2014). The L. monocytogenes isolates were inoculated into Brain Heart Infusion (BHI) broth and incubated for 24 hours at $37^{\circ} \mathrm{C}$. After that, $200 \mu \mathrm{l}$ of each inoculum was taken on Muller Hinton agar plates and spread eventually with the help of sterile L-shaped spreader. Then the plates were allowed to dry and antibiotic discs were placed on media aseptically with the help of sterile forceps. Next, the plates were incubated at $37^{\circ} \mathrm{C}$ for $24-48$ hours. After completion of incubation the diameter of zone of inhibition was compared with the standard known value against each specific antimicrobial agent from interpretation guide line (Hi-Media) ${ }^{\circledR}$.

\section{Results and Discussion}

Isolation and identification of $L$. monocytogenes

Out of 200 different samples from cattle sources (cattle faeces, raw milk and milk products) of Aizawl, a total 29 (14.50\%) samples were found to be positive for Listeria spp. by the cultural method in which isolates turned into black colour in different broth (FB and UVM) and also showed different characteristics of colonies on different agars such as green colonies with black haloes in PALCAM agar, dense white to iridescent white appearing as crushed glass in McBride agar and clean glass like colonies in TSYEA agar after $24-48$ hours of incubation at $37^{\circ} \mathrm{C}$. Based on the Gram staining reaction and different biochemical tests (catalase: positive:; oxidase: negative: tumbling motility; indole: negative; methyl red: positive; VogesProskauer: positive citrate: negative; L- 
rhamnose: positive; D- Mannitol fermentation: negative; D- Xylose fermentation: negative, weak haemolysis on sheep blood agar and positive CAMP test against Staphylococcus aureus characteristics), 13 (6.50\%) numbers of L. monocytogenes were identified and the findings were in accordance with Gupta and Sharma (2012) and Walse et al., (2003) (Table 5, 6 and Figure 1-12).

The detection of Listeria spp. from food products is challenging due to the concurrence presence of other organisms within the food product. In this respect, the isolation method in respect to specific pathogen is critical and must allow recovery and detection of injured cells too. In food, detection of Listeria spp. is generally performed in a two-step cultural enrichment process and along with selective supplements like antibacterial and antifungal agents. The bacteriological culture methods commonly used for detection and identification of the bacteria include aesculin and ferric iron in enrichment or plating media, which results through the hydrolysing capacity of Listeria spp., in the formation of intense black colour (Fraser and Sperber, 1988). Results of in vitro pathogenicity tests showed that Listeria spp. brought about haemolysis on five per cent SBA similar to the earlier records of Blanco et al., (2008). The Christie Atkins Munch-Petersen (CAMP) test is a unique confirmatory tool for identification of this food borne pathogen. The Listeria spp. isolates recovered during the study have shown the positive CAMP pattern against $S$. aureus (ISO, 1996).

Prevalence of $L$. monocytogenes in different samples of cattle sources (faeces, raw milk and milk products) from Aizawl, Mizoram

The prevalence of $L$. monocytogenes was recorded as 6.50 percent (13/200) comprised of 8.00 percent (4/50) strains from cattle faeces, 6.00 percent (3/50) from raw milk,
8.00 percent $(2 / 25)$ from lassi, dahi and icecream samples, respectively (Table 7 and Figure 13). Listeria monocytogenes was detected from the raw milk and ready to eat refrigerated milk products produced locally from unpasteurized milk like dahi, lassi and ice-cream whereas the organism was not isolated from rasmalai which is a well-cooked milk product stored for a short duration of time in the sweet shops. The Higher prevalence rates of $L$. monocytogenes from faecal samples of ruminants were recorded by Lawan et al., (2003) (10.00\%) and Kalorey et al., (2006) (16.00\%) from Nigria and Nagpur (India), respectively. Waghmare, (2006) evaluated the incidence of Listeria spp. in raw milk from different markets of Mumbai city (India) and revealed prevalence of Listeria spp. and L. monocytogenes amongst the pasteurized milk samples with the incidence of 21.32 and 5.88 per cent in unpasteurized milk samples. Similarly, Chandio et al., (2007) reported 6.00 per cent of L. monocytogenes in raw cow milk where as higher incidence of prevalence of L. monocytogenes (21. 70\%) was reported by Sharma et al., (2012) from 115 raw cow milk samples in Meerut and Babugarh Cantt, Hapur, India. In contrast, studies conducted at Coimbatore (Tamilnadu) and Mangalore, India reported that branded milks were more prone to $L$. monocytogenes than the local milk (Dhanashree et al., 2003; Sheela and Muthukmar, 2011). However, Moharram et al., (2007) reported 5.00 percent incidence of L. monocytogenes from nonbranded ice-cream samples from different ice cream parlours of Mysore (India).

The seasonal distribution of L. monocytogenes revealed 4.95 and 8.08 percent of prevalence in summer and winter season, respectively. The Seasonal fluctuation of L. monocytogenes in the milk has been reported as 1.69 per cent in summer and 3.82 per cent in winter (Aurora et al., 2006) (Table 8 and Figure 14). 
Table.1 Distribution of different samples of cattle sources collected from Aizawl district of Mizoram

\begin{tabular}{|c|c|c|c|c|c|}
\hline \multirow[t]{2}{*}{ Sl. No } & \multirow[t]{2}{*}{ State } & \multirow[t]{2}{*}{ Type of sample } & \multirow[t]{2}{*}{ Number of samples } & \multicolumn{2}{|c|}{ Seasonal distribution } \\
\hline & & & & Summer & Winter \\
\hline 1 & \multirow{6}{*}{$\begin{array}{c}\text { Aizawl } \\
\text { (Mizoram) }\end{array}$} & Cattle faeces & 50 & 25 & 25 \\
\hline 2 & & Raw cow milk & 50 & 25 & 25 \\
\hline 3 & & Lassi & 25 & 13 & 12 \\
\hline 4 & & Dahi & 25 & 13 & 12 \\
\hline 5 & & Ice-cream & 25 & 12 & 13 \\
\hline 6 & & Rasmalai & 25 & 13 & 12 \\
\hline \multicolumn{3}{|c|}{ Total } & 200 & 101 & 99 \\
\hline
\end{tabular}

Table.2 Oligonucleotide primers used for detection of species specific gene of L. monocytogenes by PCR

\begin{tabular}{|c|c|c|c|}
\hline $\begin{array}{l}\text { Target } \\
\text { Genes }\end{array}$ & Primer Sequence (5'-3') & $\begin{array}{c}\text { Base } \\
\text { Pair (bp) }\end{array}$ & Reference \\
\hline $\begin{array}{l}16 S r- \\
R N A\end{array}$ & $\begin{array}{l}\text { F- } \\
\text { GGACCGGGGCTAATACCGAATGATAA } \\
\text { R- TTCATGTAGGCGAGTTGCAGCCTA }\end{array}$ & 1200 & $\begin{array}{l}\text { Weidmann } \\
\text { et al.,(1993) }\end{array}$ \\
\hline
\end{tabular}

Table.3 Composition of PCR reaction mixture for detection of species specific gene and virulence genes of L. monocytogenes

\begin{tabular}{|c|}
\hline SI. No. \\
\hline 1 \\
\hline 2 \\
\hline 3 \\
\hline 4 \\
\hline 5 \\
\hline
\end{tabular}

\begin{tabular}{|c|c|}
\hline Ingredients & Volume $(\boldsymbol{\mu l})$ \\
\hline PCR Master Mixture 2x & 12.5 \\
\hline Forward primer & 1 \\
\hline Reverse primer & 1 \\
\hline Template & 4 \\
\hline Milli-Q water & 6.5 \\
\hline Total & $\mathbf{2 5 . 0}$ \\
\hline
\end{tabular}

Table.4 Thermal cycling condition for detection of species specific (16S-rRNA) gene of L. monocytogenes

\begin{tabular}{|c|c|c|}
\hline SI. No & Stages & PCR for $16 \mathrm{Sr}-R N A$ gene of $L$. monocytogenes \\
\hline 1 & Initial denaturation & $94^{\circ} \mathrm{C}$ for $4 \mathrm{~min}$ \\
\hline 2 & Denaturation & $94^{\circ} \mathrm{C}$ for $30 \mathrm{sec}$ \\
\hline 3 & Annealing & $56.5^{\circ} \mathrm{C} 45 \mathrm{sec}$ \\
\hline 4 & Elongation & $72^{\circ} \mathrm{C}$ for $30 \mathrm{sec}$ \\
\hline 5 & Final Extension for 1 cycle & $72^{\circ} \mathrm{C}$ for $3 \mathrm{~min}$ \\
\hline & No. of cycle & $\mathbf{3 5}$ \\
\hline
\end{tabular}


Table.5 Morphological and biochemical test results of L. monocytogenes

\begin{tabular}{|c|c|c|}
\hline SI. No. & Morphological/biochemical test & Positive characteristics \\
\hline $\mathbf{1}$ & Gram staining & Positive \\
\hline $\mathbf{2}$ & Catalase & Positive \\
\hline 3 & Oxidase & Negative \\
\hline 4 & Motility & Tumbling \\
\hline $\mathbf{5}$ & Indole & Negative \\
\hline 6 & Methyl Red & Positive \\
\hline 7 & Voges-Proskauer & Positive \\
\hline $\mathbf{8}$ & Citrate & Negative \\
\hline 9 & L-Rhamnose fermentation & Positive \\
\hline 10 & D- Mannitol fermentation & Negative \\
\hline 11 & D- Xylose fermentation & Negative \\
\hline
\end{tabular}

Table.6 Listeria monocytogenes isolation by cultural method and confirmed by biochemical test collected from different source of cattle of Aizawl (Mizoram) district

\begin{tabular}{|c|c|c|c|c|c|}
\hline $\begin{array}{l}\text { Sl. } \\
\text { No. }\end{array}$ & State & $\begin{array}{l}\text { Type of } \\
\text { sample }\end{array}$ & $\begin{array}{l}\text { Number } \\
\text { of } \\
\text { samples } \\
\text { analyzed }\end{array}$ & $\begin{array}{l}\text { Number of } \\
\text { samples positive } \\
\text { for Listeria spp. by } \\
\text { cultural method }\end{array}$ & $\begin{array}{l}\text { Number of samples } \\
\text { positive for } L \text {. } \\
\text { monocytogenes after } \\
\text { biochemical test }\end{array}$ \\
\hline 1 & \multirow{6}{*}{$\begin{array}{c}\text { Aizawl } \\
\text { (Mizoram) }\end{array}$} & Cattle faeces & 50 & 7 & 4 \\
\hline 2 & & Raw cow milk & 50 & 9 & 3 \\
\hline 3 & & Lassi & 25 & 4 & 2 \\
\hline 4 & & Dahi & 25 & 4 & 2 \\
\hline 5 & & Ice-cream & 25 & 5 & 2 \\
\hline 6 & & Rasmalai & 25 & - & - \\
\hline \multicolumn{3}{|c|}{ Total } & 200 & 29 & 13 \\
\hline
\end{tabular}

Table.7 Prevalence of L. monocytogenes in different samples of cattle source from Aizawl (Mizoram) district $(\mathrm{n}=200)$

\begin{tabular}{|c|c|c|c|c|c|}
\hline $\begin{array}{l}\text { Sl. } \\
\text { No. }\end{array}$ & State & $\begin{array}{l}\text { Type of } \\
\text { sample }\end{array}$ & $\begin{array}{l}\text { Number of } \\
\text { samples } \\
\text { analyzed }\end{array}$ & $\begin{array}{l}\text { Number of } \\
\text { sample positive } \\
\text { for } L \text {. } \\
\text { monocytogenes }\end{array}$ & $\begin{array}{c}\text { \% prevalence of } \\
\text { L. } \\
\text { monocytogenes }\end{array}$ \\
\hline 1 & \multirow{6}{*}{$\begin{array}{c}\text { Aizawl } \\
\text { (Mizoram) }\end{array}$} & Cattle faeces & 50 & 4 & 8.00 \\
\hline 2 & & Raw milk & 50 & 3 & 6.00 \\
\hline 3 & & Lassi & 25 & 2 & 8.00 \\
\hline 4 & & Dahi & 25 & 2 & 8.00 \\
\hline 5 & & Ice-cream & 25 & 2 & 8.00 \\
\hline 6 & & Rasmalai & 25 & 0 & 0.00 \\
\hline \multicolumn{3}{|c|}{ Total } & 200 & 13 & 6.50 \\
\hline
\end{tabular}


Table.8 Season wise prevalence of L. monocytogenes isolated from different samples of cattle source from Aizawl (Mizoram) district

\begin{tabular}{|c|c|c|c|c|c|c|}
\hline \multirow[t]{2}{*}{$\begin{array}{l}\text { Sl. } \\
\text { No. }\end{array}$} & \multirow[t]{2}{*}{ State } & \multirow[t]{2}{*}{$\begin{array}{l}\text { Type of } \\
\text { sample }\end{array}$} & \multirow{2}{*}{$\begin{array}{l}\text { Number } \\
\text { of sample } \\
\text { tested in } \\
\text { winter }\end{array}$} & \multirow{2}{*}{$\begin{array}{l}\text { Number } \\
\text { of sample } \\
\text { tested in } \\
\text { winter }\end{array}$} & \multicolumn{2}{|c|}{$\begin{array}{c}\text { Seasonal distribution of } L \text {. } \\
\text { monocytogenes }\end{array}$} \\
\hline & & & & & $\begin{array}{l}\text { Prevalence } \\
\text { in summer }\end{array}$ & $\begin{array}{l}\text { Prevalence in } \\
\text { winter }\end{array}$ \\
\hline 1 & \multirow{6}{*}{$\begin{array}{l}\text { Aizawl } \\
\text { (Mizoram) }\end{array}$} & $\begin{array}{l}\text { Cattle } \\
\text { faeces }\end{array}$ & 25 & 25 & $1(4.00 \%)$ & $3(12.00 \%)$ \\
\hline 2 & & Raw milk & 25 & 25 & $1(4.00 \%)$ & $2(8.00 \%)$ \\
\hline 3 & & Lassi & 13 & 12 & $1(7.69 \%)$ & $1(8.33 \%)$ \\
\hline 4 & & Dahi & 13 & 12 & $1(7.69 \%)$ & $1(8.33 \%)$ \\
\hline 5 & & Ice-cream & 12 & 13 & $1(8.33 \%)$ & $1(7.69 \%)$ \\
\hline 6 & & Rasmalai & 13 & 12 & - & - \\
\hline & Total & & 101 & 99 & $5(4.95 \%)$ & $8(8.08 \%)$ \\
\hline
\end{tabular}

Table.9 Antibiotic Sensitivity and Resistance pattern of L. monocytogenes isolated from different samples of cattle source of Aizawl (Mizoram) district

\begin{tabular}{|c|c|c|c|c|c|c|c|c|}
\hline \multirow{3}{*}{$\begin{array}{l}\text { Sl. } \\
\text { No. } \\
1\end{array}$} & \multirow{3}{*}{$\begin{array}{l}\text { Antimicrobial agent } \\
\text { Penicillin G (P) }\end{array}$} & \multirow{3}{*}{$\begin{array}{l}\text { No. of } \\
\text { isolates } \\
13\end{array}$} & \multicolumn{6}{|c|}{ L. monocytogenes isolated from cattle faeces } \\
\hline & & & \multicolumn{2}{|c|}{$\begin{array}{l}\text { Sensitive } \\
(\%)\end{array}$} & \multicolumn{2}{|c|}{$\begin{array}{c}\text { Intermediate } \\
(\%)\end{array}$} & \multicolumn{2}{|c|}{ Resistance $(\%)$} \\
\hline & & & 13 & 100 & - & - & - & - \\
\hline 2 & Ampicillin (AMP) & 13 & 13 & 100 & - & - & - & - \\
\hline 3 & Oxacillin $(\mathrm{OX})$ & 13 & 13 & 100 & - & - & - & - \\
\hline 4 & Streptomycin (HLS) & 13 & 11 & 84.61 & 2 & 15.38 & - & - \\
\hline 5 & Erythromycin (E) & 13 & - & - & 1 & 7.69 & 12 & 92.30 \\
\hline 6 & $\begin{array}{c}\text { Cephotaxime / } \\
\text { Clavulanic acid (CEC) }\end{array}$ & 13 & 13 & 100 & - & - & - & - \\
\hline 7 & Ceftriaxone (CTR) & 13 & 6 & 46.15 & - & - & 7 & 53.84 \\
\hline 8 & Chloramphenicol (C) & 13 & 7 & 53.84 & 2 & 15.38 & 4 & 30.76 \\
\hline 9 & Ciprofloxacin (CIP) & 13 & 13 & 100 & - & - & - & - \\
\hline 10 & Gentamicin (GEN) & 13 & 7 & 53.84 & - & - & 6 & 46.15 \\
\hline 11 & Tetracycline (TE) & 13 & 13 & 100 & - & - & - & - \\
\hline 12 & $\begin{array}{l}\text { Trimethoprim/Sulpha } \\
\text { methoxazole (COT) }\end{array}$ & 13 & 13 & 100 & - & - & - & - \\
\hline
\end{tabular}




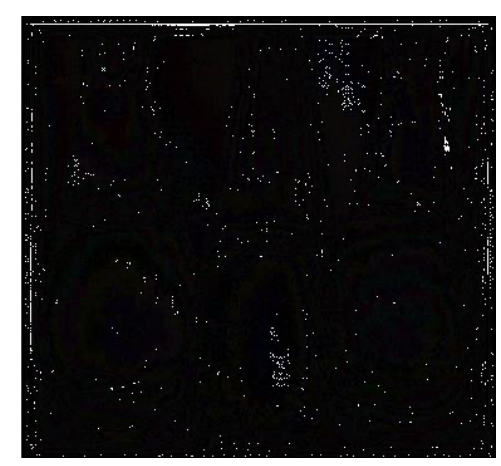

Figure 1: Milk products with UVM -I

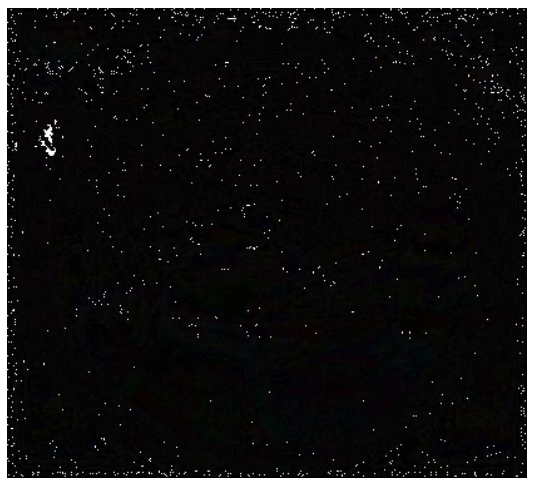

Figure 4: L. monocytogenes on TSYEA agar

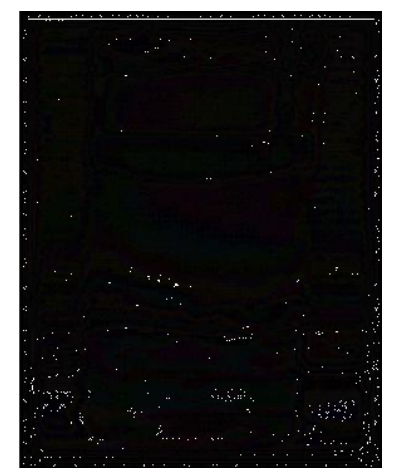

Figure 7: $L$.

monocytogenes showing umbrella shaped growth in Listeria motility

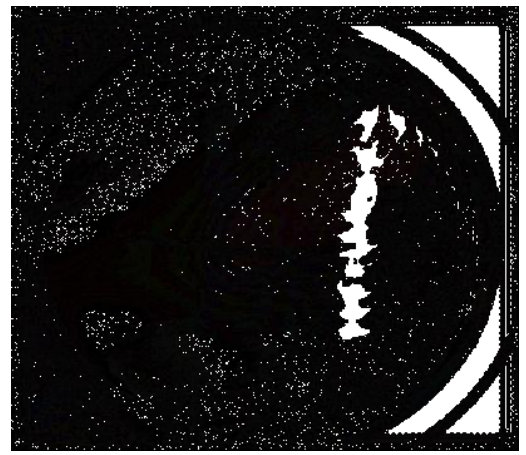

Figure 2: L. monocytogenes on PALCAM agar

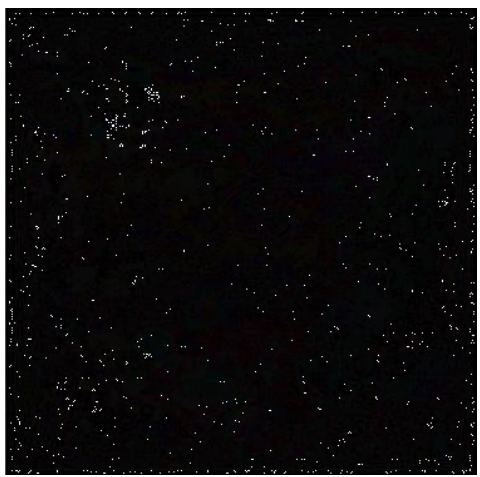

Figure 5: L. monocytogenes showing gram staining positive

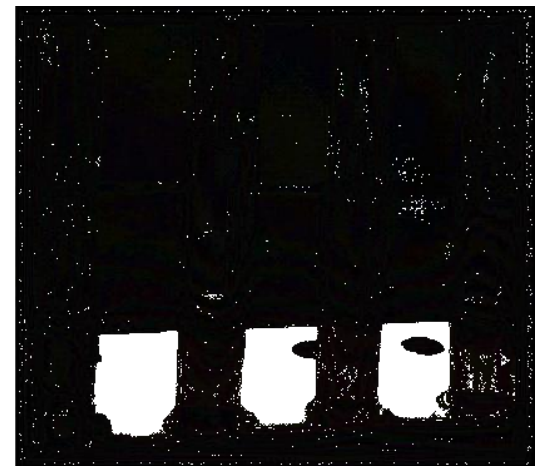

Figur e 8: IMVIC test showing MR and VP +ve for $L$. monocytogenes

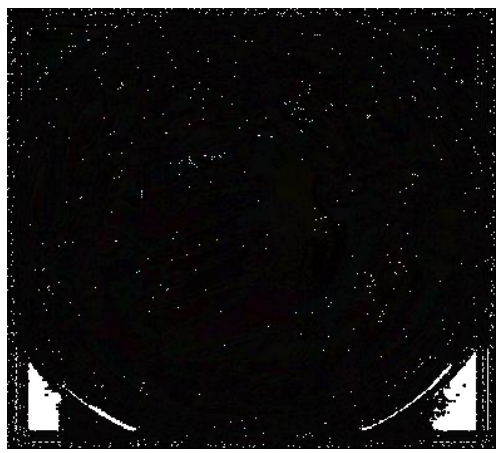

Figure 3: L. monocytogenes on McBride agar

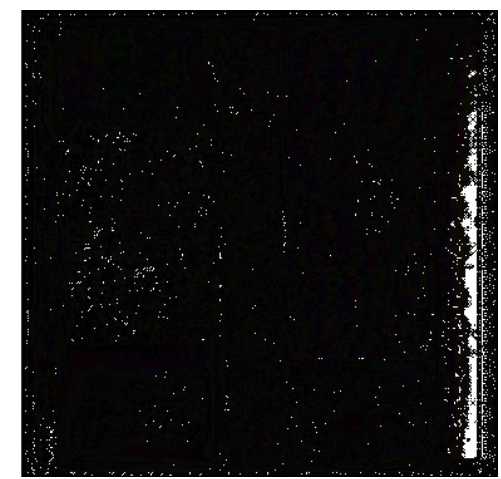

Figure 6: L. monocytogenes showing oxidase negative and Catalase positive

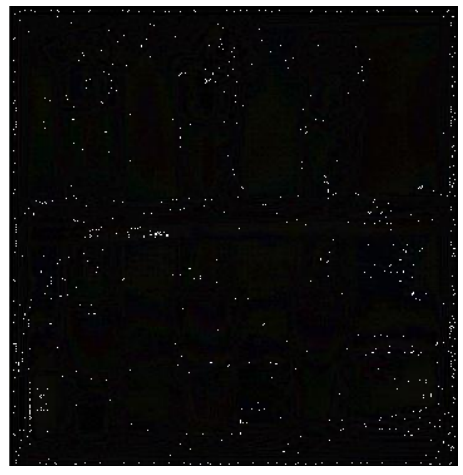

Figure 9: Sugar fermentation tests for $L$. monocytogenes (Rhamnose $+v e$, Xylose and Mannitol ve) 


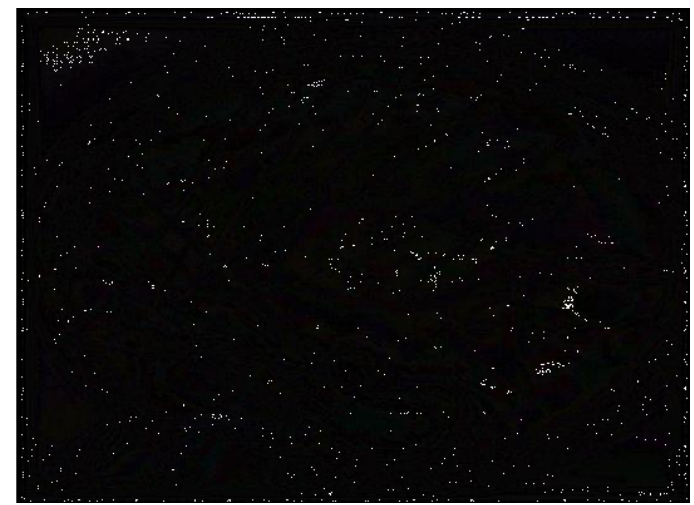

Figure 10: L. monocytogenes showing weak ? -haemolysis on SBA

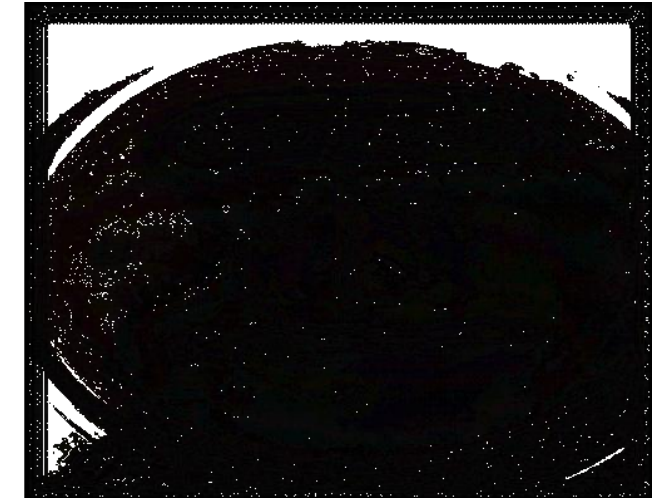

Figure 11: L. monocytogenes showing positivity in CAMP test

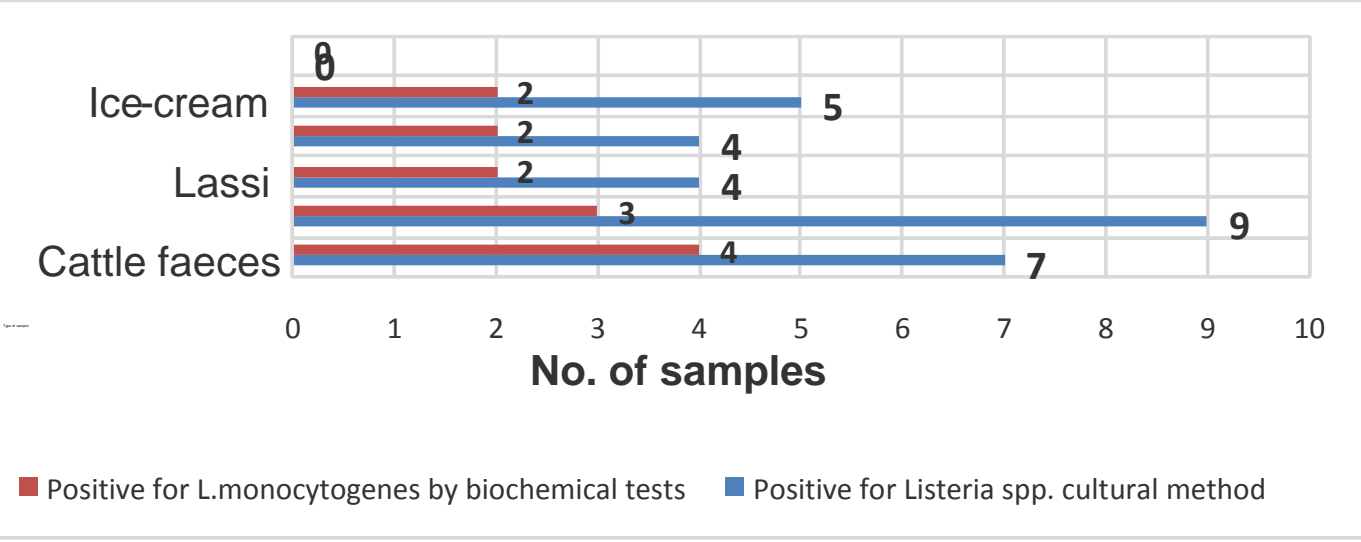

Figure 12: Detection of Listeria monocytogenes from different samples of cattle source from Aizawl (Mizoram) district by cultural method $(n=200)$

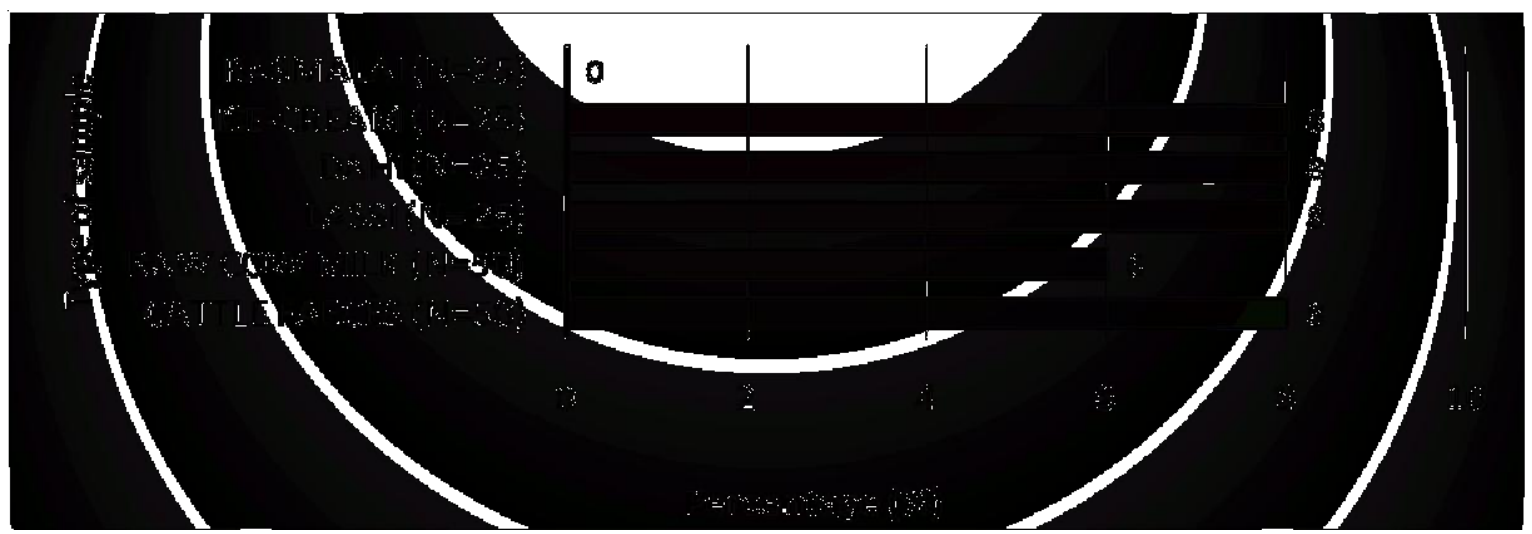

Figure -13 Prevalence of $L$. monocytogenes in different samples of cattle source from Aizawl (Mizoram) district $(\mathrm{n}=\mathbf{2 0 0})$ 


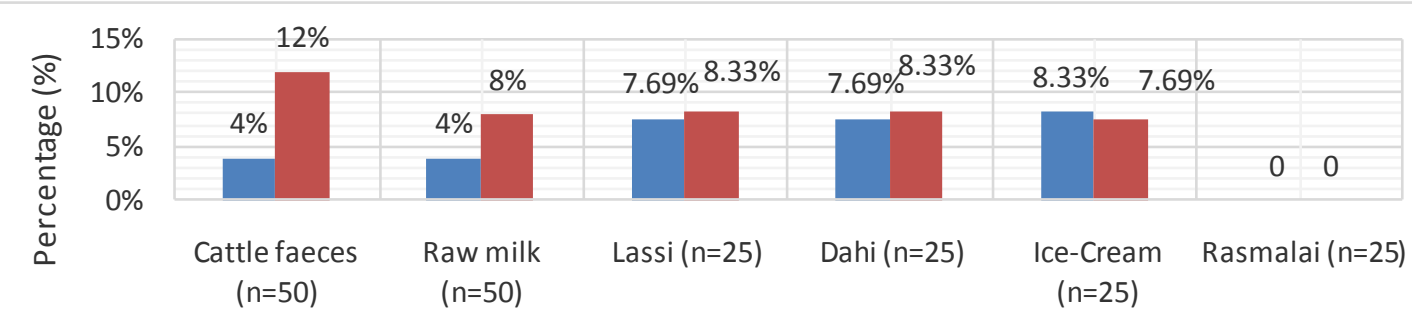

Type of sample

- Prevalence in Summer $\quad$ Prevalence in Winter

Figure 14: Season wise prevalence of $L$. monocytogenes isolated from different samples of cattle source from Aizawl (Mizoram) district $(\mathbf{n = 2 0 0})$

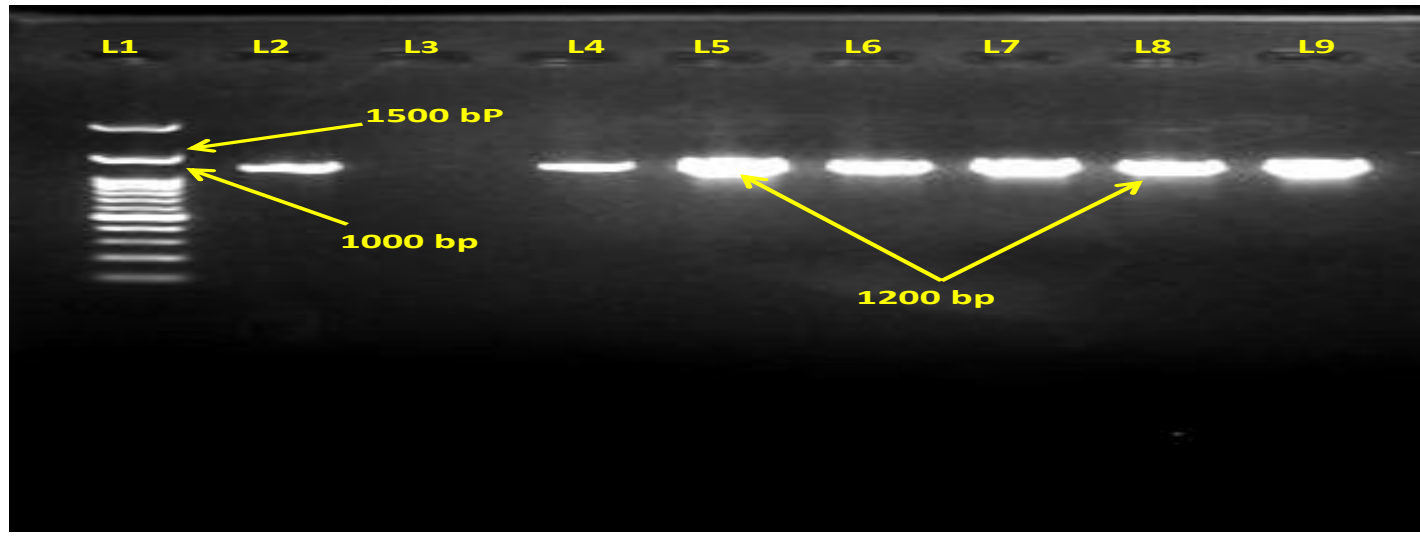

Figure-15: Agarose gel electrophoresis showing the PCR amplicons of 16S-rRNA gene (1200bp) obtained from $L$. monocytogenes strains; L1: 3000 bp DNA ladder; L2: Positive control; L3: Negative control; L4 to L9: Representative samples

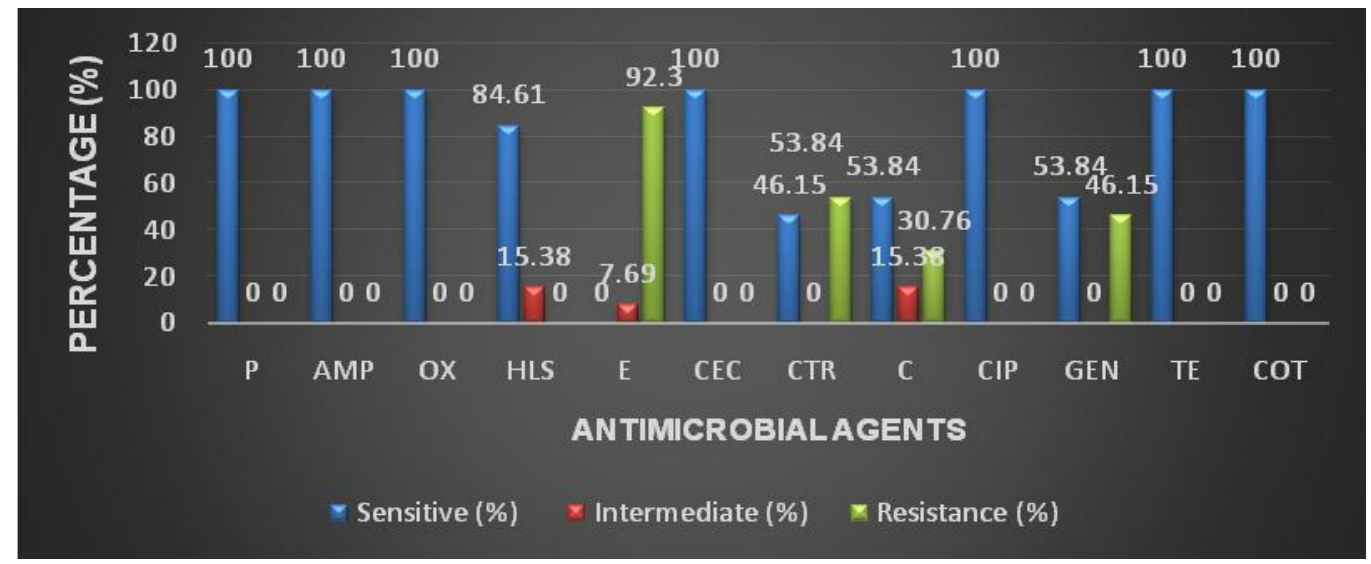

Figure 16: Antibiotic sensitivity and resistance pattern of $L$. monocytogenes isolated from different samples of cattle source of Aizawl (Mizoram) district 
Listeria is a widely distributed bacterium in nature and commonly found in soil, sewage, dust, water and causes listeriosis in humans and animals (Norton et al., 2001). Of the various milk pathogens, L. monocytogenes is one of the deadly organisms which occurs largely in all types of environment, including foods grown in contaminated environment, poorly processed/stored food, milk and associated products (Priyanka and Alka, 2008). The study of incidence of Listeria spp. in cattle faeces, milk and milk products in their selling units provide information about the carrier status in cattle and contamination status of the milk and milk products.

The milk producing and processing environment and handling practices may vary place to place and production practices.

There are chances of increase in cross contamination as 47 per cent of surface of hand of the food handlers and 16 per cent on the processing tables were found to carry $L$. monocytogenes (Kerr et al., 1993; Jayasekaran et al., 1996). The presence of Listeria spp. particularly L. monocytogenes in ready to eat milk products like dahi, lassi, ice cream and raw milk could be a major food safety issue for consumers as $L$. monocytogenes should be absent in RTE foods (US-FDA) (Fusch et al., 1992).

Detection of species specific gene (16S$r R N A$ ) of $L$. monocytogenes in different samples of cattle source

The culturally, phenotypically and biochemically positive 13 numbers of $L$. monocytogenes isolates were subjected for $16 S$ - $r R N A$ species specific gene amplification using the standardized PCR protocol by using published primer. All the 13 numbers of $L$. monocytogenes strains isolated from Aizawl districts of Mizoram were positive for $16 \mathrm{~S}$ rRNA gene (Figure 15).

\section{Antibiotic sensitivity pattern of $L$. monocytogenes}

All the 13 L. monocytogenes strains showed 100 percent sensitivity towards Penicillin, Ampicillin, Oxacillin, Cephotaxime/ Clavulanic acid, Ciprofloxacin, Tetracycline and Trimethoprim/ Sulphamethoxazole followed by Streptomycin (84.61\%), Chloramphenicol (53.84\%), Gentamicin $(53.84 \%)$ and Ceftriaxone (46.15\%). Conversely the L. monocytogenes strains showed highest resistance to Erythromycin $(92.30 \%)$, Ceftriaxone (53.84\%), Gentamicin (46.15\%) and Chloramphenicol (30.76\%), respectively (Table 9 and Figure 16).

There is growing concern of bacterial adaptation and evolution resulting in the emergence of antimicrobial resistant bacteria pathogens since last 50 years. The prevalence of antimicrobial resistance among food borne pathogens has increased during recent decades (Akbar and Anal, 2014). The frequent and unnecessary use of antimicrobial agents in food animals for therapeutic and prophylactic purposes in animals are contributing to create resistant strains. Animal origin foods are the major sources of transmission of antimicrobial resistant organisms to human. The antimicrobial resistant bacteria from food animals may colonize the human population via food chain, contact through occupational exposure or waste run off from animal production facilities. Resistant bacteria may readily transferred from food animals to human beings as the similar kind of antimicrobial agents are used in human practice also, therefore the detection of antimicrobial resistance pattern is a matter of public health significance. Sharma et al., (2012) detected 80-90 percent resistance of $L$. monocytogenes strains from raw milk of Meerut and Babugarh Cantt, Hapur (India) to Nalidixic acid, Amoxycillin + Sulbactum, Vancomycin, 
Kanamycin, Cloxacillin, and Erythromicin whereas many were susceptible to the Ampicillin, Ofloxacin, Tetracycline, Streptomycin, Sulphafurazole, Oxacilin and Ciprofloxacin.

The findings of Sharma et al., (2017) is alarming as they recently isolated Multi Drug Resistant (MDR) strains of L. monocytogenes from raw milk in Rajasthan and emphasized on the need of awareness among consumers.

Implementation of food safety regulations at different levels of milk production has come up as a great public health issue.

The present study detected the $L$. monocytogenes, a major zoonotic pathogen causing fatal infections in human by conventional and molecular detection methods in different samples of cattle sources namely faeces, raw milk and milk products in the study area indicating the public health significance of the pathogen.

The presence of the organism in cattle faeces indicated the carrier status and the presence in raw milk and refrigerated milk products produced locally and sold in local markets under unhygienic condition is alarming public health threat to the consumers.

The well-cooked milk product (Rasmalai) which is stored for a short period of time has been found to be free from L. monocytogenes.

\section{Acknowledgements}

The authors duly acknowledge to the Dean, College of Veterinary Sciences \& Animal Husbandry, Central Agricultural University, Selesih, Aizawl, Mizoram for providing the funds with necessary facilities to conduct this study under the Department of Veterinary Public Health and Epidemiology.

\section{References}

Akbar, A., and Anal, A.K. 2014. Zinc oxide nanoparticles loaded active packaging a challenge study against Salmonella typhimurium and Staphylococcus aureus ready-to-eat poultry meat. Food Contr., 38:88-95.

Atil, E., Ertas, H.B., and Ozbey, G. 2011.Isolation and molecular characterization of Listeria spp. From animals, food and environmental samples. Vet. Med., 56: 386394.

Aurora, A., Prakash, A., and Prakash, S. 2006. Occurrence of pathogenic Listeria monocytogenes in raw milk and ready to eat milk products in Agra city. India. Indian. J. Comp. Microbiol. Immunol. Infect. Dis., 27(2): 87-93.

Bauer, A.W., Kirby, W.M.M., Sherris, J.C., and Turck, M. 1966. Antibiotic susceptibility testing by a standardized single disc method. Amer. J. Clin. Patho., 45:493-496.

Blanco, M. B., Fernandez-Garayzabal, J. F., Dominguez, L., Briones, V., VazquezBoland, J. A., Blanco, J. L., Garcia, J. A., and Suarez, G. 2008. A technique for the direct identification of haemolytic pathogenic Listeria on selective plating media. Lett. Al. Microbiol., 9:125-128.

Chandio, T.H., Soomro, A.H., Bhutto, M.B., Dewani, P., and Shah, G. 2007. Occurrence of Listeria monocytogenes in bovine milk in Hyderabad, Pakistan. Ann. Microbiol., 57:341- 344.

CLSI (2014). Performance Standards for Antimicrobial Microbial Susceptibility testing $18^{\text {th }}$ Information supplement M100-S18. Wany, PA: Clinical and Laboratory Standards Institute.

Dhanashree, B., Otta, S.K., and Karunasagar, I. 2003. Typing of Listeria monocytogenes isolates by random 
amplification of polymorphic DNA. Indian J. Med. Res., 117:19-24.

FDA 2015. Testing methodology for $L$. monocytogenes in environmental samples. Version 1.

Fraser, J.A., and Sperber, W.H. 1988. Rapid detection of Listeria spp. in food and environmental samples by esculin hydrolysis. J. Food Prot., 51:762-765.

Fusch, R.S., and Reilly, P.J.A. 1992. The incidence and significance of in sea foods. In: H. H. Huss, and M. Jackobsen (ed), Proceeding of an International Conference on -Quality Assurance in the Fish industryll, Copenhagen, Denmark pp. 217-230.

Gupta, S., and Sharma, V. 2012. Antibiotic resistance pattern among different Listeria species isolated from mutton and chevon. J. Anim. Res., 3: 99-102.

International Organization for Standardization, 1996. Microbiology of food and animal feeding stuffsHorizontal method for detection and enumeration of Listeria monocytogenespart-1: Detection method. International Standard ISO11290-1, Geneva, Switzerland.

Jallewar, P.K., Kalorey, D.R., Kurkure, N.V., Pande, V.V., and Barbuddhe, S.B. 2007. Genotypic characterization of Listeria spp. isolated from fresh water fish. Int. J. Food Microbiol., 114: 120-123.

Jayasekaran, G., Karunasagar, I., and Karunasagar, I. 1996. Incidence of Listeria species in tropical fish. Int.J. Food Microbiol., 31: 333-340.

Kalorey, D.R., Kurkure, S.R., Rawool, D.B., Mallik, S.V.S., and Barbuddhe, S.B. 2006. Isolation of pathogenic Listeria monocytogenes in faeces of wild animals in captivity. Comp. Immunol, Microbiol. Inf. Dis., 29:295-300.

Kerr, K.G., Birkenhead, D., Seale, K., Major, J., and Hawkey, P.M. 1993 Prevalence of Listeria spp. on the hands of food workers. J. Food Prot., 56:525-527.

Lado, B., and Yousef, A. E. 2007 Characteristics of Listeria monocyotgenes important to food processors, Chapt. 6. In: Ryser E T and Marth E H (Eds), Listeria, listeriosis and food safety, 3rd edn, CRC Press Taylor and Francis Group, Boca Raton. Pp. 157-213.

Lawan, F. A., Tijjani, A. N., Raufu, A. I., Ameh, J. A., Ngoshe, I. Y., and Auwal, M.S. 2003. Isolation and characterization of Listeria species from ruminants in Maiduguri north-eastern Nigeria. Afr. J. Biotechnol., 12(50):6997-7001.

Moharram, M., CharithRaj, A.P., and Janardhana, G.R. 2007. Prevalence of Listeria monocytogenes in ice creams sold in Mysore city and detection by Polymerase Chain Reaction (PCR). Asian J. Microbiol. Biotechnol. Environ. Sci., 9:151-154.

Norton, D.M., McCamey, M.A., Gall, K.L., Scarlett, J.M., Boor, K.J., and Wiedmann, M. 2001. Molecular studies on the ecology of Listeria monocytogenes in the smoked fish processing industry. Appl. Environ. Microbiol., 67: 198-205.

Priyanka, S., and Alka, P. 2008. Isolation of Escherichia coli, Staphylococcus aureus and Listeria monocytogenes from milk products sold under market conditions at Agra region. Acta agriculturae Slovenica., 92: 83-88.

Quinn, P.J., Carter, M.E., Markey, B.K., and Carter, G.R. 1994. General procedures in microbiology. Clin. Vet. Microbiol. Wolfe Publishing, London, pp. 648.

Rocourt, J., and Catimel, B. 1985. Biochemical characterization of species in the genus Listeria. Zentralble Bakteriologika Mikrobiol. Hyg., 260:221 231. 
Schlech III, W.F., and Acheson, D. 2000. Foodborne listeriosis. Clin. Infect. Dis., 31(3): 770-775.

Sharma, D., Sharma, P.K., Saharan, B.S., and Malik, A. 2012. Isolation, identification and antibiotic susceptibility profiling of antimicrobial resistant Listeria monocytogenes from dairy milk. Int. J. Microbial. Res. Technol., 1: 1-4.

Sharma, S., Sharma, V., Dahiya, D.K., Khan, A., Mathur, M., and Sharma, A. 2017. Prevalence, virulence potential, and antibiotic susceptibility profile of Listeria monocytogenes isolated from bovine raw milk samples obtained from Rajasthan, India. Foodborne. Pathog. Dis., 14(3): 132-140.

Sheela, M.M., and Muthukmar, M. 2011. Effectiveness of Ozone to Inactivate the Listeria monocytogenes from the Milk samples. World J. Young Researchers., 1(3): $40-44$.

United States Department of Agriculture Food Safety and Inspection Service (FSIS) (2002). Isolation and Identification of Listeria monocytogenes from Red Meat, Poultry, Egg and Environmental Samples, Revision 03, April 29, 2002. In: Microbiol. Lab. Guidebook. pp 1-21.

Waghmare, R.N. 2006. Prevalence and Molecular characterization of Listeria monocytogenes from milk. Thesis, M.V.Sc, MAFSU, Bombay Veterinary College, Mumbai.

Wagner, M., Podstatzky-Lichtens, L., Lethner, A., Asperger, H., Baumgarther, W., and Brand, E. 2000. Prolonged excretion of Listeria monocytogenes in a subclinical case of mastitis. Milchwisschaft, 55: 36 .

Walse, S.H., Paturkar, A.M., Sherikar, A.T., Waskar, V.S., Zende, R.J., and Vaidya, V.M. 2003. Prevalence of Listeria spp. in mutton and chevon. J. Vet. Pub. Health., 1:65-68.

Weidmann, M., Barany, F., and Batt, C.A. 1993. Detection of Listeria monocytogenes with a nonisotopic polymerase chain reaction-coupled ligase chain assay. Appl. Environ. Microbiol., 59(8): 2743-2745.

\section{How to cite this article:}

Papia Biswas, Devajani Deka, T.K. Dutta, E. Motina and Roychoudhury, P. 2018. Conventional and Molecular Detection of Listeria monocytogenes and its Antibiotic Sensitivity Profile from Cattle Sources of Aizawl, Mizoram (India). Int.J.Curr.Microbiol.App.Sci. 7(11): 2829-2843. doi: https://doi.org/10.20546/ijcmas.2018.711.326 